\title{
Organizational strategy for the development of nurses' competences: possibilities of Continuing Education in Health
}

\author{
Estratégia organizacional para o desenvolvimento de competências de enfermeiros: possibilidades de \\ Educação Permanente em Saúde
Estrategia organizacional para el desarrollo de competencias de enfermeros: posibilidades de Educación Permanente en Salud

\author{
Amanda de Lemos Mello \\ Lana Jocasta de Souza Brito ${ }^{2}$ \\ Marlene Gomes Terra ${ }^{1}$ \\ Silvia Henriques Camelo²
}

1. Universidade Federal de Santa Maria. Santa Maria, RS, Brazil.

2. Universidade de São Paulo. Ribeirão Preto, SP, Brazil.
Corresponding author: Amanda de Lemos Mello E-mail: amandamello6@yahoo.com

Submitted on $06 / 30 / 2017$. Accepted on 11/06/2017.

DOI: 10.1590/2177-9465-EAN-2017-0192

\begin{abstract}
Objective: To reflect on Continuing Education in Health as an organizational strategy for the development of nurses' competences. Methods: A theoretical-reflective study was performed, combining concepts from Continuing Education in Health, organizational strategy and professional competence, understood as key elements for the work of nurses in health services. Results: To understand how to live together, individuals need to have knowledge about others, their history and traditions. When "learning how to do", they acquire broader competence to deal with unexpected situations and to facilitate team work. With regard to "learning how to be", they are encouraged to acquire autonomy and discernment on behalf of the group. If the focus is on development rather than control, there is shared interest and an integrated and strategic model for nurses' competences to be improved. Conclusion: The development of competences in nurses is the basis for the Learning Paths as a possible operationalization of Continuing Education in Health.
\end{abstract}

Keywords: Nursing; Staff Development; Professional Competence; Strategies.

\section{Resumo}

Objetivo: Refletir sobre Educação Permanente em Saúde como estratégia organizacional para o desenvolvimento de competências de enfermeiros. Método: Estudo teórico-reflexivo, de entrelaçamento das concepções de Educação Permanente em Saúde, estratégia organizacional e competência profissional, compreendidos como elementos-chave para a atuação dos enfermeiros nos serviços de saúde. Resultados: Para aprender a viver juntos é preciso existir conhecimento em relação aos outros, sua história e tradições. No aprender a fazer, a pessoa adquire competência mais ampla para lidar com situações inesperadas e facilitar o trabalho em equipe. Em aprender a ser instiga o sujeito para adquirir autonomia e discernimento, em prol de um coletivo. Conclusão: Se o foco for no desenvolvimento e não no controle, há interesse conciliado e um modelo integrado e estratégico para que as competências dos enfermeiros sejam desenvolvidas. O desenvolvimento de competências nos enfermeiros embasa as Trilhas de Aprendizagem como possibilidade de operacionalizar a Educação Permanente em Saúde.

Palavras-chave: Enfermagem; Desenvolvimento de Pessoal; Competência Profissional; Estratégias.

\section{Resumen}

Objetivo: Reflexionar sobre Educación Permanente en Salud como estrategia organizacional para el desarrollo de competencias de enfermeros. Método: Estudio teórico-reflexivo, de entrelazamiento de concepciones de Educación Permanente en Salud, estrategia organizacional y competencia profesional, comprendidos como elementos clave para la actuación de los enfermeros en los servicios de salud. Resultados: Para aprender a vivir juntos, hay que existir conocimiento en relación a los demás, su historia y tradiciones. En el aprender a hacer, la persona adquiere competencia más amplia para lidiar con situaciones inesperadas y facilitar el trabajo en equipo. En aprender a ser, instiga al sujeto para adquirir autonomía y discernimiento, con enfoque en un colectivo. Conclusión: Si el foco es en el desarrollo, hay interés conciliado y un modelo integrado y estratégico para que las competencias de los enfermeros sean desarrolladas, lo que confiere a las Rutas de Aprendizaje la posibilidad de operacionalizar la Educación Permanente en Salud.

Palabras clave: Enfermería; Desarrollo de Personal; Competência Profissional; Estratégias. 


\section{INTRODUCTION}

The constant transformations and advances in health care, especially in the nursing work process, have required investments in professional qualification, aiming to better understand the needs of the population. In addition, they have established that user and professional satisfaction is the result to be obtained, taking into consideration the complex context of health establishments, which require continuous reflection due to the competences needed from some of the professionals. ${ }^{1,2}$ During this time, Educação Permanente em Saúde (EPS Continuing Education in Health) appears as a possibility of innovation and (re)organization of the work process through in-service education ${ }^{3}$, aimed at strengthening the development of competences of nursing professionals.

Professional competence can be understood as a mobilization and integration of values, knowledge, abilities and attitudes, essential for work performance. ${ }^{4}$ To achieve this, the construction of nursing competences aims to adjust professional qualification to the new requirements of health care practices and integrate it to the local and regional context of the work process. ${ }^{5}$

In this perspective, the new management models, especially in the area of nursing, seek to plan and develop the qualification process of health teams in a participatory way. ${ }^{6}$ In health organization, EPS can be considered as an organizational strategy, enabling the work process to be discussed in an integrated way on several levels, such as health care, social control, management and qualification. ${ }^{7}$

To think EPS as a possible organizational strategy to develop nursing competences can contribute to health professionals' reflection. Thus, based on their actions in the work-qualification process, nurses can contribute to the planning, organization and development of both the management and health care practices, aiming to promote an innovative, reflective and critical approach. ${ }^{7}$

This theoretical-reflective study sought to combine this possibility with EPS National Policy principles, organizational strategy and nursing competences, here understood as key elements for the work of health service professionals. Aiming to follow this reflective path, the interrelations between these theoretical branches and their approaches were identified, so that the context of the proposals here presented could be understood.

In light of this situation, the following question arose: How can EPS become an institutional strategy for the development of nursing competences? Thus, the present study aimed to reflect on EPS as a possible organizational strategy for the development of nursing competences.

\section{Continuing Education in Health in the context of professional competences}

EPS was created to develop effective relationships between education and health care and it was improved by the Brazilian Health Reform to include the relationships among qualification, management and social control in health. ${ }^{7}$ The historical basis of EPS is pointed out in some studies from the logic that it emerges as a strategy to bring about changes in work processes, as a new model for the development of qualification not based on specific courses aimed at professional "recycling", dissociated from the remaining elements and actions comprising health care. ${ }^{8,9}$

The constant transformations in health care showed the urgency for the construction of educational processes that follow changes to practices. Thus, the main intention of the EPS is to develop meaningful learning through the interaction of teams from multiple areas that work in a certain context, considering the fact that health actions have an inter-sectoral and interprofessional nature and seek comprehensive user care. ${ }^{7}$

The main point of the Meaningful Learning Theory is to assume that new knowledge can be acquired if individuals are willing to learn and if the content is significant for individuals, i.e. it takes into consideration their previous experiences. The combination of new knowledge with preexisting ideas enables individuals to create new meanings that will be unique for them. According to this theory, the qualification process, both the act of teaching and learning, means to create different situations that contribute to and promote meaningful learning. ${ }^{10}$ Starting from the idea of meaningful learning, there is the possibility of constructing knowledge according to individuals' previous understanding of this theme. Thus, previous knowledge is valued and it helps the qualification process to make sense in routine practices. $^{7-9}$

When taking these aspects into consideration, the Diretrizes Curriculares Nacionais (DCN - National Curriculum Guidelines) for Undergraduate Nursing Education indicates the general competences that nurses need for their qualification. ${ }^{11}$ Among these is EPS, which, according to the Guidelines, nurses must be able to learn continually, both during their qualification and practice. In other words, nurses must be able to learn how to learn and to be responsible for and committed to their education. The qualification process needs to provide conditions for the mutual benefit of nursing students and those who already work in health services, aiming to promote teaching-service integration. ${ }^{11}$

In light of this, EPS is a professional competence that nurses must acquire. Work in the health area requires continuing qualification and nurses must have skills, knowledge and attitudes to perform their role of facilitator of Continuing Education, aiming to develop educational actions in the workplace and for work. ${ }^{12}$

In addition to being caregivers, nurses are also educators and, consequently, possible facilitators of Continuing Education. On the one hand, these professionals are expected to make decisions based on scientific principles, exchange of experiences and guidance aimed at better individual, team and community perception. For this reason, EPS must be seen as a developer of professional competences that must follow the dynamics and changes in the professional world. ${ }^{12}$

On the other hand, the development of EPS also requires nurses to have other knowledge. Thus, this educational action is expected to be an essential part of the strategy of institutional change in health services. EPS emerges in this perspective as an organizational strategy for the development of competences. 
According to the Política Nacional de Educação Permanente em Saúde (PNEPS - Brazilian Policy on Continuing Education in Health), at times, a "global and sustainable strategy is implemented, enabling a steady and systematic achievement of such goals". 7:40-41 To achieve this, the Policy indicates the following three main questions associated with EPS:

- Not every qualification action implies a continuing education process. Although every qualification is aimed at the improvement of personnel performance, not all of these actions represent a significant part of a strategy for institutional change, a requirement for continuing education processes;

- As a systematic and global strategy, continuing education can include several specific qualification actions in its process, but not the other way around. In the context of a greater sustainable strategy, these actions can have a beginning and an end and be aimed at specific groups of workers, as long as they are integrated with the general strategy of institutional change;

- Every continuing education process requires preparation, design and execution according to a strategic analysis and the institutional culture of the health services in which it is included. . $^{70-41}$

Taking these questions into consideration, the organization requires rethinking EPS-related activities, as a comprehensive educational strategy, directed towards the development of their professionals and thus contributing to the transformation of health services.

\section{Continuing Education in Health as an organizational strategy for the development of nursing competences}

Historically, the qualification process in health and other areas was associated with specific activities that focused on a theme and were strictly formal towards the development of training, which at times were operationalized sporadically and separated from the reality of professionals and their needs. ${ }^{8}$ When problematizing EPS as an organizational strategy, the training models frequently restricted to formal courses and connected to a specific job or profession must be disregarded. ${ }^{13}$ Instead, these models must seek strategies that can contribute to both what the health organizations expect from professionals regarding competences and how they can help professionals in nursing care practice.

These learning actions, developed as an obligation, sometimes do not consider other educational possibilities or professionals' real needs. When the logic of EPS is included, any routine work situation can be a possibility for problematizing, reflecting critically and transforming practice, becoming a learning experience.$^{8}$ Considering the fact that the preparation of strategic actions in health organizations for the development of professional competences is essential for nursing care quality. ${ }^{13}$
As a possibility of organizational strategy for the development of nursing competences, the preparation of the Trilhas de Aprendizagem (TA - Learning Paths) represents an alternative and flexible way, more adequate for the analysis of the needs and concerns of individuals, aiming to promote professional and personal development. ${ }^{14,15}$ These Paths are founded on Delors' concepts when pointing out the four pillars of education: to learn how to live with others, to learn how to do, to learn how to know, and to learn how to be. ${ }^{16}$ Additionally, according to Le Boterf's concepts of "professional navigation", seen as a process of acquisition of new professional learning experiences. ${ }^{17}$

In order to learn how to live together, one must have knowledge about others, their history and traditions. To achieve this, three other pillars are required and to learn how to know enables a general culture to be harmonious and certain themes to be mastered in depth. The general culture enables continuing education, as it provides the basis for learning throughout life. ${ }^{16}$

To learn how to do allows individuals to acquire broader competences, which help them to deal with unexpected situations that promote team work. To learn how to be encourages individuals to have autonomy and discernment, especially on behalf of a group goal. ${ }^{16}$

Based on this context, the interrelation between competence and learning according to Le Boterf must also be understood. ${ }^{17}$ Professional competence results from the following three dimensions: knowledge (set of pieces of information integrated by individuals), skill (individual ability to make use of knowledge) and attitude (social and emotional aspects associated with work). This third dimension has a direct influence on the behavior of individuals regarding their acceptance of something, such as their willingness to learn. ${ }^{18}$

Le Boterf indicates that competence is knowing/acting, which is different from knowing-doing due to its purpose, in the sense that action differs from behavior because of its meaning for individuals. It is based on this context that the author understands the need to develop competences through resources that mobilize these dimensions, due to work process situations ${ }^{17}$. As a result, when the concept of competence is associated with organizational strategy, the relevance of learning processes to encourage individuals and groups is understood.

Learning Paths are included in this context as a way to give professionals the opportunity to change their thoughts and routine practices according to their needs, considering the fact that the development of competences must not be an obligation. Every individual has their tastes and preferences and, when these aspects are valued and recognized, the learning process becomes more pleasurable, productive and motivating. ${ }^{14-16}$ The Learning Paths must be taken into consideration as a strategy to help with this process, considered as multiple alternatives offered to individuals, followed according to individual, group and organization expectations, based on the competences they already have and those they still need to develop ${ }^{15}$.

To achieve this, Le Boterf indicates that, for the development of Learning Paths, learning must be seen as a voluntary act, 
when individuals need to have a reason to be committed to the educational process. Learning requires a direction to be followed, i.e. a destination where one aims to arrive at, in this case, a set of competences to be acquired ${ }^{17}$. Thus, the path to be followed depends not only on where one wants to arrive at, but also the starting point.

Furthermore, the act of being qualified through Learning Paths is like moving across a network of opportunities and not becoming entangled with a pre-established qualification curriculum or program. Thus, the learning process will depend on the wealth of teaching possibilities on the Learning Paths made available to professionals. ${ }^{17}$ In this case, what becomes relevant in this possibility is not only the journey, but also the point of arrival of the learning process. ${ }^{14,15}$

The Learning Paths enable professionals to build up their learning from their needs and choices, integrating personal planning with health organization expectations, including their ambitions, expected performance, the competences they already have and those they need to add to their knowledge. Therefore, when such factors are taken into consideration, health professionals can choose the most relevant educational resources available that suit their objectives, needs and preferences. $^{14,15}$

For the development of coherent competences that meet the expected results, the work environment must promote learning and professionals have to be interested and encouraged to learn and teach. ${ }^{17}$ Thus, the Learning Paths become a possible way to implement EPS as an organizational strategy, as it tends to gather the needs of professionals and organizations, guaranteeing the participation of each one involved. As a result, they represent the partnership between organization and workers, balancing out the needs and choices of individuals and organizational strategies, assuming the shared responsibility for the process of development of competences. ${ }^{14,15}$

For the development of competences according to this logic, organizational planning is recommended, as it can occur through the following stages: definition of essential competences for the work of nurses in health services; mapping of the competences required and definition of profiles; survey of strategies for the development of such competences; construction of an institutional policy for personnel management; possible learning paths and qualification plans according to the logic of EPS. Thus, the Learning Paths converge with the logic of EPS for the development of competences for nurses, especially because these Paths value the participation of those who are in the process of learning and recognizing the different teaching possibilities.

Based on the focus on development rather on control, there is shared interest and an integrated and strategic model so that the competences of nurses are developed. Thus, managers can help to create an environment suitable for learning, in addition to promoting and mediating different actions aimed at the qualification process. On the other hand, health teams showed an interest, revealed their professional and personal needs, and sought the opportunities and support available to define their learning path. ${ }^{14-16}$

\section{FINAL CONSIDERATIONS}

EPS can be viewed as an important organizational strategy for the development of competences of nurses, including shared planning that can guide their work practice. Aiming to develop work that converges with the principles and guidelines of Brazilian health policies, emphasis must be given to the development of attitudes, individual and group skills, and knowledge, through qualification that enables the empowerment of the participants involved and dissolves the dichotomy between theory and practice.

Thus, there is the possibility of organizing institutional actions according to the educational logic of engaging groups, constructing from the shared work with teaching and health practice institutions. Actions developed in the logic of EPS are encouraged, according to the meaningful learning practice, aiming to enable health teams to develop a critical approach to problematize the work process.

From this point on, a critical-reflexive approach committed to and aimed at others is required, especially from professionals who have management jobs and can be facilitators of this process. Moreover, for EPS to be an effective and relevant institutional strategy, the principles of dialogue, the perspective of health care and management practices, the horizontality of actions, and the importance of networking. Additionally, it can be understood that nurses are individuals with competences that support health production.

Based on the understanding of the complexity of the theme here presented, nurses can see EPS as a possible strategy to develop competences that surpass the traditional model of educational logic, aimed at vertical qualification, and that correspond to specific emergencies in health practices, without dealing with the diversity of professionals or being associated with professional needs and institution goals. However, with a broader understanding such as the Learning Paths, including questions about the context and functioning in a participatory way, individuals can obtain knowledge required to make informed decisions.

\section{ACKNOWLEDGEMENTS}

Authors would like to thank the Coordenação de Aperfeiçoamento de Pessoal de Nível Superior (CAPES Coordination for the Improvement of Higher Education Personnel) for funding the first author with a doctoral scholarship.

\section{REFERENCES}

1. Salum NC, Prado ML. A educação permanente no desenvolvimento de competências dos profissionais de enfermagem. Texto Contexto Enferm [Internet]. 2014 Apr/Jun; [cited 2017 Jun 11]; 23(2):301-8 Available from: http://www.scielo.br/pdf/tce/v23n2/pt_0104-0707tce-23-02-00301.pdf 
2. Santos APA, Camelo SHH, Santos FC, Leal LA, Silva BR. O enfermeiro no pós-operatório de cirurgia cardíaca: competências profissionais e estratégias da organização. Rev Esc Enferm USP [Internet]. 2016; [cited 2016 Jun 10]; 50(3):474-81. Available from: http://www.scielo.br/pdf/ reeusp/v50n3/pt_0080-6234-reeusp-50-03-0474.pdf

3. Sade PMC, Peres AM. Desenvolvimento de competências gerenciais do enfermeiro: diretriz para serviços de educação permanente. Rev Esc Enferm USP [Internet]. 2015; [cited 2016 Jun 10]; 49(6):991-8. Available from: http://www.scielo.br/pdf/reeusp/v49n6/pt_0080-6234reeusp-49-06-0991.pdf

4. Oliveira NB, Silva FVC, Assad LG. Competências do enfermeiro especialista em nefrologia. Rev Enferm UERJ [Internet]. 2015 May/Jun; [cited 2017 Jun 11];23(3):375-80. Available from: http://www.facenf.uerj. br/v23n3/v23n3a14.pdf

5. Fracolli LA, Castro DFA. Nursing competence in the Primary Care: a focus on the humanization of the work process. Mundo Saúde [Internet]. 2012; [cited 2016 Jun 10]; 36(3):427-32. Available from: http://www. saocamilo-sp.br/pdf/mundo_saude/95/4.pdf

6. Soares MI, Camelo SHH, Resck ZMR, Terra FS. Saberes gerenciais do enfermeiro no contexto hospitalar. Rev Bras Enferm. [Internet] $2016 \mathrm{Jul} /$ Aug; [cited 2017 Jun 14]; 69(4):676-83. Available from: http://www.scielo.br/scielo.php?script=sci_arttext\&pid=S003471672016000400676\&lng=en

7. Ministério da Saúde (BR). Secretaria de Gestão do Trabalho e da Educação na Saúde, Departamento de Gestão da Educação em Saúde. Política Nacional de Educação Permanente em Saúde [Internet]. Brasília (DF): Ministério da Saúde; 2009. [cited 2017 Feb 20]. Available from: http://bvsms.saude.gov.br/bvs/publicacoes/politica_nacional_ educacao_permanente_saude.pdf

8. Cardoso MLM, Costa PP, Costa DM, Xavier C, Souza RMP.The National Permanent Health Education Policy in Public Health Schools: reflections from practice. Ciênc Saúde Coletiva [Internet]. 2017 May; [cited 2017 May 31]; 22(5):1489-500. Available from: http://www.scielo.br/scielo. php?pid=S1413-81232017002501489\&script=sci_arttext\&tlng=en

9. Fernandes FC, Cortez EA, Laprovita D, Almeida LP, Ferreira AF, Corvino MPF. Educação permanente em saúde sob a perspectiva de Agostinho de Hipona. Rev Bras Enferm [Internet]. 2017 May/Jun; [cited 2017 May 31]; 70(3):656-61. Available from: http://www.scielo.br/scielo. php?script=sci_arttext\&pid=S0034-71672017000300656\&lng=en
10. Sousa ATO, Formiga NS, Oliveira SHS, Costa MML, Soares MJGO A utilização da teoria da aprendizagem significativa no ensino da Enfermagem. Rev Bras Enferm [Internet]. 2015 Jul/Aug; [cited 2017 May 31]; 68(4):713-22. Available from: http://www.scielo.br/scielo. php?pid=S0034-71672015000400713\&script=sci_abstract\&tlng=pt

11. Brasil. Resolução CNE/CES №. 3 de 07 de novembro de 2001 (BR). Institui Diretrizes Curriculares Nacionais do Curso de Graduação em Enfermagem. Diário Oficial da República Federativa da União [Internet]. Brasilia (DF). 9 Nov 2001. [cited 2017 Jun 4]. Available from: http://portal. mec.gov.br/cne/arquivos/pdf/CES03.pdf

12. Ferraz L, Vendruscolo $C$, Marmett $S$. Educação permanente na enfermagem: uma revisão integrativa. Rev Baiana Enferm [Internet]. 2014 May/Aug; [cited 2017 Jun 21]; 28(2):196-207. Available from: https:// portalseer.ufba.br/index.php/enfermagem/article/view/8366/8871

13. Camelo $\mathrm{SHH}$, Angerami ELS. Competência profissional: a construção de conceitos, estratégias desenvolvidas pelos serviços de saúde e implicações para a enfermagem. Texto Contexto Enferm [Internet]. 2013 Apr/Jun; [cited 2017 Jun 21]; 22(2):552-60. Available from: http://www. scielo.br/pdf/tce/v22n2/v22n2a34.pdf

14. Instituto de Pesquisa Econômica Aplicada - IPEA. Estratégias para desenvolvimento de pessoas. Brasília: Ipea; 2014. [cited 2017 Jun 21] Available from: http://ipea.gov.br/agencia/images/stories/PDFs/livros/ livros/150511_estrategias_para_desenvolvimento_de_pessoas.pdf

15. Freitas IA, Brandão HP. Trilhas de aprendizagem como estratégia de TD\&E. In: Borges-Andrade JE, Mourão L, Abbad GS, coord. Treinamento, desenvolvimento e educação em organizações e trabalho: fundamentos para a gestão de pessoas. Porto Alegre: Artmed; 2006.

16. Delors J. Educação: um tesouro a descobrir. Relatório para a UNESCO da Comissão Internacional sobre Educação para século XXI. São Paulo: Cortez; Brasília: MEC/UNESCO; 1998.

17. Le Boterf G. Compétence et Navigation Professionnelle. Paris: Éditions d'Organisation; 1997.

18. Fleury MTL, Fleury A. Construindo o conceito de competência. Rev Adm Contemp. [Internet]. 2001; [cited 2017 Ago 23]; 5(no.espe): 18396. Available from: http://www.scielo.br/scielo.php?script=sci arttext\&pid=S1415-65552001000500010\&lng=en\&nrm=iso 